\title{
Nipah Virus: A Public Health Concern
}

\author{
Abu Bakar Siddique ${ }^{1}$, Jannatul Fardows ${ }^{2}$, Nasreen Farhana ${ }^{3}$, Maksud Mazumder ${ }^{4}$ \\ Received: December 28, 2015 Accepted: April 30, 2016 \\ doi: http://dx.doi.org/10.3329/jemc.v6i2.27766
}

\begin{abstract}
Nipah virus, a member of the genus Henipavirus, a new class of virus in the Paramyxoviridae family, has drawn attention as an emerging zoonotic virus in South-East and South Asian region. Case fatality rate of Nipah virus infection ranges from 40-70\% although it has been as high as $100 \%$ in some outbreaks. Many of the outbreaks were attributed to pigs consuming fruits, partially eaten by fruit bats, and transmission of infection to humans. In Bangladesh, Nipah virus infection was associated with contact with a sick cow, consumption of fresh date palm sap (potentially contaminated with pteropid bat saliva), and person-to-person transmission. In 2014, 18 cases of Nipah virus infection have been reported in Bangladesh, of which 9 cases died. In the most recent epidemic at least 6 people died out of nine cases due to Nipah virus infection in the remote northern Bangladesh in 2015. Human infections range from asymptomatic infection to fatal encephalitis. Some people can also experience atypical pneumonia and severe respiratory problems. The virus is detected by ELISA, PCR, immunofluoroscence assay and isolation by cell culture. Treatment is mostly symptomatic and supportive as the effect of antiviral drugs is not satisfactory, and an effective vaccine is yet to be developed. So the very high case fatality addresses the need for adequate and strict control and preventive measures.
\end{abstract}

Key words: Nipha virus; Public health; Fruit bat; Outbreak

J Enam Med Col 2016; 6(2): 101-105

\section{Introduction}

Nipah virus is an emerging zoonotic virus. In infected people, Nipah virus causes severe illness characterized by inflammation of the brain or respiratory diseases. It can also cause severe disease in animals such as pigs. ${ }^{1}$ Nipah virus is closely related to Hendra virus. Both are members of the genus Henipavirus, a new class of virus in the Paramyxoviridae family. It was first isolated from a patient from Sungai Nipah village in Malaysia., 2,3 Although Nipah virus has caused only a few outbreaks, it infects a wide range of animals and causes severe disease and death in people, making it a public health concern. ${ }^{4}$ However, in Bangladesh many sporadic cases of Nipah virus encephalitis are found every year. In this review paper, transmission, clinical features, treatment, prevention and control of Nipah virus infection are discussed. Background, different outbreaks and recent outbreak in Bangladesh are also discussed.

\section{Historical background}

Human Nipah virus (NiV) infection was first recognized in a large outbreak of 276 reported cases in peninsular Malaysia and Singapore from September 1998 through May 1999.,3 Most patients had contact with sick pigs. ${ }^{5}$ At first infection occurs in bats, then to pigs and then in humans causing encephalitis with up to $40 \%$ mortality. The survivors were inflicted with residual neurological problems. ${ }^{6}$ The outbreak was attributed to pigs consuming fruits partially eaten by fruit bats, and transmission of infection to humans. Case fatality rate of the 2001 outbreak which took place

1. Assistant Registrar, Department of Medicine, Dhaka Medical College, Dhaka

2. Assistant Professor, Department of Microbiology, International Medical College, Gazipur

3. Lecturer, Department of Microbiology, Dhaka Medical College, Dhaka

4. Registrar, Department of Medicine, Popular Medical College, Dhaka

Correspondence Jannatul Fardows, Email: jannat2026@gmail.com 
in Siliguri, India and near the northern border of Bangladesh was $68 \%{ }^{7}$

\section{Outbreaks in Bangladesh}

In Bangladesh, four outbreaks of Nipah virus infection were identified during the period 2001-2004. The first identification of Nipah virus as a cause of an outbreak of encephalitis was reported in 2001 in Meherpur district of Bangladesh. ${ }^{8}$ Outbreaks were different in Bangladesh due to lack of identifiable intermediate animal hosts (i.e. pig). Outbreak in 2004 included a number of victims under 19 years of age who collected and ate fruits, partly eaten by bats under the trees before dawn. ${ }^{1}$ In Bangladesh, 135 probable or confirmed cases of Nipah virus (NiV) infection in humans were identified from 2004 through 2008; of them 98 (73\%) were fatal. ${ }^{9}$ Drinking raw date palm sap, contaminated by $\mathrm{NiV}$ from urine or saliva of Pteropus spp. fruit bats, has been identified as a vehicle for transmission of $\mathrm{NiV}$ to humans in Bangladesh. ${ }^{10,11}$ The virus was isolated from human respiratory secretions, saliva, and urine during the outbreaks. ${ }^{12,13}$ Outbreak investigations in Bangladesh have repeatedly implicated person-toperson transmission of $\mathrm{NiV}$, including health care-associated transmission. ${ }^{14,15}$ However, to our knowledge, no evidence of NiV transmission to health care workers had been confirmed in Bangladesh. ${ }^{14}$ In the area where NiV outbreaks have been repeatedly identified, the Institute for Epidemiology, Disease Control and Research (IEDCR) of the Government of Bangladesh, in collaboration with icddr,b (formerly the International Centre for Diarrhoeal Disease Research in Bangladesh) is conducting hospital-based encephalitis surveillance. On January 14, 2010, two cousins living in Faridpur district in Bangladesh were admitted to Faridpur Medical College Hospital (FMCH) with fever and altered mental status. A team from IEDCR and icddr,b initiated an investigation on January 15, 2010. At last they were diagnosed as encephalitis caused by Nipah virus. ${ }^{16}$ In 2012, a total of 12 human caes of $\mathrm{NiV}$ infection were reported, 10 (83\%) of them died. ${ }^{8}$ The next outbreak of Nipah virus has been reported in Bangladesh in 2013, with 24 cases and 21 deaths. Fourteen districts have been affected. These are Gaibandha, Natore, Rajshahi, Naogaon, Rajbari, Pabna, Jhenaidah, Mymensingh, Nilphamari, Chittagong, Kurigram, Kushtia, Magura and Manikganj. The virus is believed to have been transmitted by drinking of Nipahcontaminated raw date palm sap in all these cases. ${ }^{17} \mathrm{In}$ 2014, 18 cases of Nipah virus infection have been reported in Bangladesh, of which 9 cases died. These cases were from 11 different districts (Manikganj, Magura, Faridpur, Rangpur, Shaariatpur, Kushtia, Rajshahi, Natore, Dinajpur, Chapai Nawabganj, Naogaon). ${ }^{18}$ IEDCR have reported a total of nine human Nipah virus cases in last one year up to February 2015. Of the nine cases, health officials reported six fatalities, or a $67 \%$ case-fatality rate. ${ }^{19}$

\section{The virus}

Nipah virus is closely related to Hendra virus. Both are members of the genus Henipavirus, a new class of virus in the Paramyxoviridae family. Both viruses are public concern for their wide host range, ability to jump species barrier and high mortality they cause. ${ }^{20}$

\section{Natural host: fruit bats}

Fruit bats of the family Pteropodidae, particularly species belonging to the Pteropus genus, are the natural hosts for Nipah virus. These bats are migratory, and there is no apparent disease in fruit bats. ${ }^{21}$

\section{$\mathrm{NiV}$ transmission from bats to people}

Epidemiological investigations in Bangladesh have identified three pathways of transmission of $\mathrm{NiV}$ from bats to people. The most frequently implicated route is ingestion of fresh date palm sap. Date palm sap is harvested from December through March, particularly in west central Bangladesh. Infrared camera studies confirm that $P$. giganteus bats frequently visit date palm sap trees and lick the sap during collection. ${ }^{22} \mathrm{NiV}$ can survive for days on sugar-rich solutions such as fruit pulp. ${ }^{23}$ Most date palm sap is processed at high temperature to make molasses, but some is enjoyed as fresh juice, drunk raw within a few hours of collection. In the 2005 Nipah outbreak in Tangail district, Bangladesh, the only exposure significantly associated with illness was drinking raw date palm sap. ${ }^{24} \mathrm{~A}$ second route of transmission for NiV from bats to people in Bangladesh is via domestic animals. Fruit bats commonly drop partially eaten saliva-laden fruit. Domestic animals in Bangladesh forage for such food. Date palm sap that is contaminated with bat feces and so is unfit for human consumption is also occasionally fed to domestic animals and may become infected with $\mathrm{NiV}$, and shed the virus to other animals, including humans. Contact with a sick cow in Meherpur, Bangladesh in 2001 was strongly associated with Nipah infection. ${ }^{25}$ Third, some people may come into direct contact with $\mathrm{NiV}$ infected bat secretions. ${ }^{26}$ 


\section{Person-to-person transmission}

Several Bangladesh Nipah outbreaks resulted from person-to person transmission. The clearest illustration of person-to-person NiV transmission occurred during the Faridpur outbreak in 2004. ${ }^{14}$ Four persons who cared for the index patient, his mother, his son, his aunt, and a neighbor, became ill 15-27 days after the index patient first developed illness. During her hospitalization, the index patient's aunt was cared for by a popular religious leader who lived in a nearby village and who became ill 13 days later. ${ }^{14}$

\section{Signs and symptoms of $\mathrm{NiV}$ infection}

Human infections range from asymptomatic infection to fatal encephalitis. Infected people initially develop influenza-like symptoms of fever, headaches, myalgia, vomiting and sore throat. This can be followed by dizziness, drowsiness, altered consciousness ${ }^{27}$ and neurological signs that indicate acute encephalitis. Some people can also experience atypical pneumonia and severe respiratory problems, including acute respiratory distress. ${ }^{28}$ The incubation period varies from four to 45 days. Most people who survive acute encephalitis make a full recovery, but around $20 \%$ are left with residual neurological consequences such as persistent convulsions and personality changes. A small number of people who recover subsequently may have relapse or develop delayed onset encephalitis. ${ }^{29}$ The case fatality rate is estimated at $40-75 \%$; however, this rate can vary by outbreak depending on local capabilities for surveillance investigations. ${ }^{30,31}$

\section{Laboratory diagnosis}

Nipah virus infection can be diagnosed by a number of different tests. ${ }^{25}$

- Serum virus neutralization assay

- Virus isolation by cell culture

- Enzyme-linked immunosorbent assay (ELISA)detection of IgG and IgM

- Polymerase chain reaction (PCR) assay

- Immunofluorescence assay

- Electron microscopy

- Immunohistochemistry

Most countries in the South-East Asia Region do not have adequate facilities for diagnosing the virus. Nipah virus is classified internationally as a bio-security level (BSL) 4 agent. BSL 2 facilities are sufficient if the virus can be first inactivated during specimen collection. There are a few laboratories in which the virus can be studied safely without risk of "escaping" and infecting more people. ${ }^{32}$

\section{Treatment}

No drugs are available to treat Nipah virus infection. Intensive supportive care with treatment of symptoms is the main approach. Ribavarin may alleviate the symptoms of nausea, vomiting, and convulsions. ${ }^{33,34}$ Treatment is mostly focused on managing fever and the neurological symptoms. Severely ill individuals need to be hospitalized and may require the use of a ventilator. ${ }^{35}$

\section{Prevention and control}

\section{Controlling Nipah virus in domestic animals}

There is no vaccine against Nipah virus. Routine cleaning and disinfection of pig farms (with sodium hypochlorite or other detergents) is expected to be effective in preventing infection. ${ }^{1}$ If an outbreak is suspected, the animal premises should be quarantined immediately. Culling of infected animals, with close supervision of burial or incineration of carcasses, is necessary to reduce the risk of transmission to people. Restricting or banning the movement of animals from infected farms to other areas can reduce the spread of the disease. As Nipah virus outbreaks in domestic animals have preceded human cases, establishing an animal health surveillance system to detect new cases is essential in providing early warning for veterinary and human public health authorities. ${ }^{1}$

\section{Reducing the risk of infection in people ${ }^{1}$}

In the absence of a vaccine, the only way to reduce infection in people is by raising awareness of the risk factors and educating people about the measures they can take to reduce exposure to the virus. Public health educational messages should focus on

- Reducing the risk of bat-to-human transmission Efforts to prevent transmission should first focus on decreasing bat access to date palm sap. Freshly collected date palm juice should also be boiled and fruits should be thoroughly washed and peeled before consumption.

- Reducing the risk of human-to-human transmission Close physical contact with Nipah virus-infected people should be avoided. Gloves and protective equipment should be worn when taking care of ill people. Regular hand washing should be carried out after caring for or visiting sick people. 
- Reducing the risk of animal-to-human transmission Gloves and other protective clothing should be worn while handling sick animals or their tissues, and during slaughtering and culling procedures.

\section{Controlling infection in health-care settings}

Health-care workers caring for patients with suspected or confirmed Nipah virus infection, or handling specimens from them should implement standard infection control precautions. Samples taken from people and animals with suspected Nipah virus infection should be handled by trained staff working in suitably equipped laboratories. ${ }^{7}$

\section{Efforts in development of an effective vaccine}

A vaccine is being developed. A recombinant subunit vaccine formulation protects against lethal Nipah virus challenge in cats. ${ }^{36}$ ALVAC Canary pox vectored Nipah $\mathrm{F}$ and $\mathrm{G}$ vaccine appears to be a promising vaccine for swine and has potential as a vaccine for humans. ${ }^{37}$ Cholesterol group is added to HRC peptides against Nipah virus targets to enhance their antiviral effect. These peptides are active to the membrane where fusion occurs and dramatically increases their antiviral effect because of increased ability to penetrate CNS. ${ }^{39}$

\section{Conclusion}

Nipah virus is a newly emerging potentially deadly infectious agent. The main strategy is to prevent Nipah virus infection in humans before it grows beyond manageable proportion. Establishing appropriate surveillance systems will be necessary so that Nipah virus outbreaks can be detected quickly and appropriate control measures can be initiated early.

\section{Acknowledgement}

Thanks to Dr. Maksud Mazumder, Registrar, Department of Medicine, Popular Medical College, Dhaka and Dr. Nazma Khatun, Lecturer, Department of Microbiology, Sahid Tajuddin Ahmed Medical College, Gazipur for their contribution in data collection and scientific advice.

\section{References}

1. WHO (World Health Organization). WHO fact sheet of Nipah virus. Available at: www.who.int/mediacentre/ factsheets/fs262/en/. Accessed November 2015.

2. Chua KB, Bellini WJ, Rota PA. Nipah virus: a recently emergent deadly paramyxovirus. Science J Clin Virol 2000; 288: 1432-1435.
3. Chua KB. Nipah virus outbreak in Malaysia. J Clin Virol 2003; 26: 265-275

4. WHO (World Health Organization). Nipah Virus Infection. Available at: www.searo. who.int/LinkFiles/CDS_Nipah_ Virus.pdf. Accessed October 2015.

5. Parashar UD, Sunn LM, Ong F. Case-control study of risk factors for human infection with a new zoonotic paramyxovirus, Nipah virus, during a 1998-1999 outbreak of severe encephalitis in Malaysia. J Infect Dis 2000; 181: $1755-1759$.

6. Ling AE. Lesson to be learnt from Nipah virus outbreak in Singapore. Singapore Med J 1999; 40(05): 223-228.

7. Wahed F, Kader SA, Begum A, Mahamud MM. Nipah virus: an emergent deadly Paramyxovirus infection in Bangladesh. J Bangladesh Soc Physiol 2011; 6(2): 134-139.

8. WHO (World Health Organization). Nipah virus outbreaks in the South-East Asia Region. WHO fact sheet, 2012. Available at: www.searo.who.int/.../a_brief_guide_emergin. Accessed November 2015.

9. Luby SP, Gurley ES, Hossain MJ. Transmission of human infection with Nipah virus. Clin Infect Dis 2009; 49: 34-39.

10. Luby SP, Rahman M, Hossain MJ, Blum LS, Husain MM, Gurley E. Foodborne transmission of Nipah virus, Bangladesh. Emerg Infect Dis 2006; 12: 1888-1894.

11. Rahman MA, Hossain MJ, Sultana S, Homaira N, Khan SU, Rahman M. Date palm sap linked to Nipah virus outbreak in Bangladesh, 2008. Vector Borne Zoonotic Dis 2012; 12: 65-72.

12. Chua KB, Lam SK, Goh KJ, Hooi PS, Ksiazek TG, Kamaruzzaman A. The presence of Nipah virus in respiratory secretions and urine of patients during an outbreak of Nipah virus encephalitis in Malaysia. J Infect 2001; 42: 40-43.

13. Harcourt BH, Lowe L, Tamin A, Liu X, Bankamp B, Bowden N. Genetic characterization of Nipah virus, Bangladesh, 2004. Emerg Infect Dis 2005; 11: 1594-1597.

14. Gurley ES, Montgomery JM, Hossain MJ, Islam MR, Molla MA, Shamsuzzaman SM. Risk of nosocomial transmission of Nipah virus in a Bangladesh hospital. Infect Control Hosp Epidemiol 2007; 28: 740-742.

15. Homaira N, Rahman M, Hossain MJ, Epstein JH, Sultana R, Khan MSU. Nipah virus outbreak with person-to-person transmission in a district of Bangladesh. Epidemiol Infect 2010; 138: 1630-1636.

16. Hossain MS, Sazzad M, Hossain J, Emily S, Parven S, Labib I. Nipah virus infection outbreak with nosocomial and corpse-to-human transmission, Bangladesh. Emerg Infect Dis 2013; 19 (2): 210-217.

17. WHO (World Health Organization). Nipah virus outbreak in 
Bangladesh. WHO fact sheet, 2013. Available at: www.searo.who.int/.../a_brief_guide_emergin. Accessed November 2015.

18. IEDCR (Institute of Epidemiology, Disease Control and Research), Nipah virus infection, 2014. Available at: www.iedcr.org/index.php?option=com_content $\&$ view $=$ article\&id. Accessed July 2014.

19. IEDCR (Institute of Epidemiology, Disease Control and Research), Nipha virus case, 2015. Available at: www.iedcr.org/index.php?option=com_content $\&$ view $=$ article\&id. Accessed September 2015.

20. Paramyxoviruses and rubella virus. In: Brooks GF, Carroll KC, Butel JS, Morse SA, Mietzner TA (eds). Jawetz, Melnick, \& Adelberg's medical microbiology. $25^{\text {th }}$ edn. Boston: McGraw Hill, 2010: 584-597.

21. Chowdhury MAJ, Shumy F. Natural host for Nipha virus [Editorial]. BSMMU J 2011; 4(1): 45.

22. Khan M, Nahar N, Sultana R, Hossain M, Gurley ES, Luby $\mathrm{S}$. Understanding bats access to date palm sap: identifying preventative techniques for Nipah virus transmission. New Orleans: American Society Trop Med Hygiene 2008; 4(3): 331-333.

23. Fogarty R, Halpin K, Hyatt AD, Daszak P, Mungall BA. Henipavirus susceptibility to environmental variables. Virus Res 2008; 132: 140-144.

24. Luby SP, Rahman M, Hossain MJ, Montgomery JM, Ahmed M, Homaera F. Foodborne transmission of Nipah virus, Bangladesh. Emerg Infect Dis 2006; 12: 1888-1894.

25. Hasan VP, Hossain MJ, Parashar UD. Nipah virus encephalitis reemergence, Bangladesh. Emerg Infect Dis 2004; 10: 2082-2087.

26. Montgomery JM, Hossain MJ, Gurley E, Luby SP, Rahman $\mathrm{M}$, Ahmed M et al. Risk factors for Nipah virus encephalitis in Bangladesh. Emerg Infect Dis 2008; 14: 1526-1532.

27. Goh K J, Tan CT, Chew NK, Tan PSK, Adeeba K, Sarj SA. Clinical features of Nipah virus encephalitis among pig farmers in Malaysia. N Engl J Med 2000; 342: 1229-1235.
28. Williamson MM, Torres FJ. Henipavirus: a review of laboratory animal pathology. Vet Pathol 2010; 47(5): 871-880.

29. Chan LY, Ali MRM, Hassan SS, Siddique AB. Human neuronal cell protein responses to Nipah virus infection. Virol J 2007; 4: 54-59.

30. Walpita P, Barr J, Sherman M, Basler CF, Wang L. Vaccine potential of Nipah virus-like particles . P LoS ONE 2011; 6(4): 12-19.

31. Dockrell DH, Sundar S, Angus BJ, Hobson RR. Infectious disease. In: Colledge NR, Walker BR, Ralston SH (eds). Davidson's principle and practice of medicine. $21^{\mathrm{st}}$ edn. Edinburgh. Churchill Livingstone Elsevier, 2010: 289-381.

32. Daniels P, Ksiazek TG, Eaton BT. Laboratory diagnosis of Nipah virus and Hendra infections. Microbes Infect 2001; 4(3): 289-295.

33. Baden LR, Dolin R. Antiviral chemotherapy, excluding antiretroviral drugs. In: Fauci AS, Braunwald E, Kasper DL, Hauser SL, Longo DL, Jamson JL et al (eds). Harrison's principles of internal medicine. $17^{\text {th }}$ edn. New York: McGraw Hill, 2008: 1090-1095.

34. Snell NJC. Ribavirin therapy for Nipah virus infection. J Virol 2004; 78(18): 10211-10214.

35. Nipah virus infection. Available at: www.searo. who. int/LinkFiles/CDS_Nipah_Virus.pdf. Accessed November 2015.

36. McEachern JA, Bingham J, Crameri G, Green DJ, Hancock TJ, Middleton D. A recombinant subunit vaccine formulation protects against lethal Nipah virus challenge in cats. Vaccine. 2008; 26(31): 3842-3852.

37. Weingartl BS. Recombinant Nipah virus vaccines protect pigs against infection. J Virol 2006; 9: 7929-7938.

38. Porotto M, Rockx B, Yokoyama CC, Talekar A, DeVito I. Inhibition of Nipah vrus infection in vivo: targeting an early stage of Paramyxovirus fusion activation during viral entry. PLoS Pathol 2010; 6(10): e1001168. 